\title{
YLEISTEN KIELITUTKINTOJEN ARVIOIJIEN KÄSITYKSIÄ THAINKIELISEKSI TUNNISTETTUJEN SUOMENOPPIJOIDEN SUULLISESTA KIELITAIDOSTA
}

\author{
Sari Ahola, Jyväskylän yliopisto, \\ Soveltavan kielentutkimuksen keskus
}

Artikkelissa tarkastellaan sitä, miten thainkielisten suomenoppijoiden $(\mathrm{N}=10)$ ensikielen tunnistaminen vaikuttaa Yleisten kielitutkintojen (YKI) suomen arvioijien ( $\mathrm{N}=44)$ käsityksiin kielitaidosta ja millaisia käsityksiä arvioijilla on thainkielisten suullisesta kielitaidosta. Artikkelin aineisto liittyy Rikkinäistä suomea-hankkeeseen, jossa thainkieliset oli yksi tutkimukseen osallistuneesta ensikielen ryhmittymästä. Artikkelissa määrällisen aineiston avulla tarkastellaan tunnistamista ja arvioinnissa käytettyjen kuuden analyyttisen arviointikriteerin käyttöä. Laadullinen aineisto koostuu arvioijien kirjoittamista ensikielen tunnistamiseen ja oppijoiden kielitaitoon liittyvistä huomioista, joiden analyysissä hyödynnetään teoriaohjaavaa sisällönanalyysia.

Arvioijat tunnistivat hyvin naiset $(\mathrm{N}=8)$ thainkielisiksi, mutta miesten $(\mathrm{N}=2)$ ensikieltä ei tunnistettu. Tunnistamisella oli vaikutusta taitotasoarvioihin: tunnistetut saivat huonompia arvioita ääntämisestä ja rakenteiden tarkkuudesta, mutta heitä palkittiin sujuvuudesta ja yleiskriteerin hallinnasta. Arvioijista thainkielisten oli vaikea oppia ensikielensä vuoksi kohdekielinen ääntäminen. Rakenteelliset puutteet taas olivat seurausta formaalin opetuksen puutteesta. Thainkielisten kielitaidon vahvuutena pidettiin sujuvuutta, johon liittyi aktiivisuus tuottaa puhetta. Yleiskriteerin arviot olivat yhteydessä oppijan tuotoksen ymmärrettävyyteen. Käsityksiin oppijoiden taidosta vaikuttivat myös tiedot thainkielisten elämästä Suomessa ja erityisesti naisiin liittyvät stereotyyppiset ajattelumallit.

Avainsanat: arvioijat, kielitaidon arviointi, kielitaitokäsitykset, suomenoppijat, suullinen kielitaito, thainkieliset

\footnotetext{
Kirjoittajan yhteystiedot:

Sari Ahola

sari.ahola@jyu.fi
} 


\section{JOHDANTO}

Tässä artikkelissa tarkastelen sitä, miten hyvin Yleisten kielitutkintojen (Yki) suomen kielen arvioijat tunnistavat thainkieliset S2-oppijat ja mikä merkitys tunnistamisella on heidän käsityksiinsä thainkielisten suomen kielen taidosta. Tunnistamisen kautta pyrin löytämään vastauksen myös laajempaan kysymykseen: millaisia käsityksiä Yleisten kielitutkintojen arvioijilla on thainkielisten oppijoiden suomen kielen suullisesta taidosta. Artikkelin tavoitteena on tuottaa lisätietoa arvioinnin taustalla vaikuttavista kielitaitokäsityksistä, ja sitä kautta tehdä arvioijat tietoiseksi omista arviointiin liittyvistä käsityksistään (ks. Tarnanen, 2002).

Yleisissä kielitutkinnoissa arvioidaan testisuorituksia, mikä tarkoittaa sitä, että päinvastoin kuin esimerkiksi oppimisen arvioinnissa koulussa arvioijat eivät tunne arvioitavia eikä heillä ole muuta tietoa arvioitavan taidosta kuin hänen antamansa näyttö testitilanteessa. Tätä näyttöä verrataan arviointitilanteessa sanallisiin kuvauksiin kielitaidon tasoista. Arviointikäyttäytymistä seurataan Yleisissä kielitutkinnoissa tilastollisten analyysien avulla, mutta tilastollisilla analyyseillä ei saada selville käyttäytymisen syitä. Koska testiarvioinnilla on merkittävä rooli yhteiskunnassa (esim. kansalaisuuden edellytyksenä olevan kielitaidon osoittaminen, työnhaku ja opiskelu) tarvitaan arvioinnin luotettavuuden parantamiseksi myös tietoa arvioijien kielitaitokäsityksistä ja arviointipäätöksiin vaikuttavista tekijöistä.

Aikaisemmat kielitaitokäsityksiin liittyvät tutkimukset Suomessa ovat keskittyneet pääasiassa opettajien ja oppijoiden kielitaitokäsityksiin (esim. Honko, 2017; Ilola, 2018), mutta testijärjestelmissä toimivien arvioijien kielitaitokäsityksiin liittyvää tutkimusta on julkaistu vain muutama. Tarnanen (2002) tutki väitöskirjassaan, millaisia käsityksiä ar- vioijilla on kirjoittamisen taidosta ja arvioinnista sekä mitkä konstruktit ohjaavat arviointia. Aholan (2012; 2016; 2020) ja Aholan ja Tossavaisen (2016) Yleisiin kielitutkintoihin liittyvissä tutkimuksissa on tarkasteltu arvioijien ja tehtävän laatijoiden käsityksiä arvioinnista, tehtävien laadinnasta ja vironkielisten oppijoiden arviointiin ja kielitaitoon liittyviä käsityksiä. Näiden aikaisempien tutkimusten perusteella arvioijien toimintaa ohjaavat käsitykset tiettyjen kielitaidon piirteiden, kuten rakenteiden ja sanaston, tärkeydestä. Tässä artikkelissa pyrin lisäämään tietoa siitä, miten puhumisen arvioinnissa oppijan ensikielen tunnistaminen vaikuttaa arviointikäyttäytymiseen ja arvioijien käsityksiin oppijoiden kielitaidosta. Lisäksi kiinnostus tutkia arviointikäyttäytymiseen liittyviä kielitaitokäsityksiä nousee myös omasta positiostani arvioijien kouluttajana; kokemukset koulutustilaisuuksista antavat viitteitä siihen, että arvioijien toimintaa ohjaavat tiettyjen kriteereiden arvostamisen lisäksi myös kriteereiden ulkopuoliset, oppijan ensikieleen ja persoonaan liittyvät tekijät.

Thainkieliset valitsin artikkelini tutkimuskohteeksi, koska artikkelini liittyy Suomen Akatemian rahoittamaan (2018-2022) Rikkinäistä suomea -Aksenttien arviointi yhteiskunnallisena portinvartijana -tutkimushankkeeseen (ks. luku 4). Hankkeessa tutkitaan aksentin vaikutusta puhumisen arvioinnissa, ja thainkieliset ovat hankkeessa yksi tutkimukseen osallistuneesta viidestä ensikielen ryhmästä. Thainkieliset valittiin hankkeeseen, koska suomen prosodia tuottaa heille vaikeuksia (Aho, Toivola, Karlsson \& Lennes, 2016) ja se on yhteydessä ensikielen tunnistamiseen. Lisäksi he muodostavat yhden Ykin suurimmista ensikielen ryhmittymistä ja myös Suomessa yhden suurimmista maahanmuuttajaryhmistä (SVT, 2018). Valintaan vaikuttivat myös thainkielisiin liittyvät stereotypiat, esimerkiksi nuoret thaivaimot ja 
thaimaalaiset marjanpoimija (Lumio, 2014; Shinyela, 2012; Sirkkilä, 2005), koska stereotypioiden on todettu vaikuttavan käsityksiin oppijan taidosta. Leinonen (2015) on aiemmin todennut tutkiessaan nuorten käsityksiä vieraalla aksentilla tuotetusta suomesta, että erilaisilla stereotyyppisillä käsityksillä on vaikutusta arviointiin. Vierasperäinen aksentti ei ainoastaan vaikuta puhujan kielitaidosta tehtävään arvioon, vaan arvioihin linkittyvät arvioijan oma arvomaailma ja omat kokemukset kieltenoppijoista (Leinonen, 2015).

Vaikka thainkieliset ovat lukumäärältään merkittävä toisen kielen oppijaryhmä Suomessa, heidän suomen oppimiseensa ja kielitaitoonsa liittyvä tutkimus on ollut vähäistä. Mustonen (2005) tarkasteli pro gradussaan, miten thain kielen merkitysten muodostaminen eroaa suomen kielestä ja kuinka thainkieliset suomenoppijat käyttävät näitä kahta kieltä hyväkseen luodessaan merkityksiä. Nikonen (2012) taas tutki pro gradussaan thainkielisten S2-oppijoiden kysymisen keinoja prosodian näkökulmasta. Hänen mukaansa thainkielisille haastavaa suomen kielessä ovat ennen kaikkea intonaatio ja lauserakenteet, joiden oppimisesta he hyötyisivät eniten tavoitellessaan kohdekielenomaista ääntämystä.

Koska tämän artikkelin keskiössä on ensikielen tunnistamisen vaikutus arvioijien käsityksiin suomen oppijoiden kielitaidosta, Ahon ym. (2016) tekemä aikuisten maahanmuuttajien suomen ääntämiseen liittyvä tutkimus antaa hyödyllistä tutkimustietoa thainkielisten suomen kielen fonologian hallintaan liittyvistä vaikeuksista. Thai ja suomi eroavat kielinä toisistaan hyvin paljon morfologiselta typologialtaan ja ne edustavat kahta erilaista kieliryhmittymää. Thai on isoloiva eli analyyttinen kieli ja suomi puolestaan edustaa agglutinoivaa kieliryhmää. Analyyttisissä kielissä kieliopilliset suhteet ilmaistaan sanajärjestyksen ja itsenäisten sanojen avulla, kun taas suomen kaltaisissa agglutinoivissa kielissä sanojen vartaloon liitettyjen taivutuspäätteiden avulla ilmaistaan kieliopillisia funktioita. Rakenteellisten ja sanastollisten erilaisuuksien lisäksi suomen kielen ääntäminen vaatii thainkielisiltä muita suomenoppijaryhmiä enemmän harjoittelua, koska thain kielestä puuttuvat suomen kielen sanoissa esiintyvät keskeiset etuvokaalit $y$, $\ddot{a}$ ja ö, ja suomen konsonantit $l, v$, $b$ ja $n$ taas äännetään eri tavoin kuin omassa ensikielessä. Thai on myös toonikieli, jossa sävelkorkeudella ilmaistaan sanojen merkityksiä. Tunnistettava aksentti syntyykin siitä, että thainkieliset siirtävät ensikielestään suomen kieleen poikkeavan sävelkulun. (Aho ym., 2016.)

\section{SUULLISEN KIELITAIDON ARVIOINTIIN VAIKUTTAVAT KÄSITYKSET}

Yleisissä kielitutkinnoissa puhumisen arviointia ohjaavat 6-portaiset arviointikriteerit, joissa on sanallisesti kuvattu arvioitavan taidon piirteet. Suullisen kielitaidon arviointia ohjaavat kriteerit rakentuvat monien eri piirteiden kuvauksista; sujuvuudesta, joustavuudesta ${ }^{1}$, ilmaisun ja rakenteiden tarkkuudesta, ääntämisestä ja sidosteisuudesta/koherenssista. Arvioinnin yksi haasteista onkin, kuinka saada arvioijat huomioimaan kaikki suulliseen kielitaitoon liittyvät piirteet arviointiprosessin aikana ja tulkitsemaan kriteereiden sisällöt samalla tavoin (Eckes, 2005; Orr, 2002). Ennen arviointia järjestettävä koulutus, jossa arvioijat tutustuvat arviointikriteereihin, puhumisen maamerkkinäytteisiin ja tehtäviin, edistää yhdenmukaisuutta ja kriteereiden monipuolista käyttöä, mutta koulutuksesta huolimatta arvioijat usein pyrkivät pitämään varsin tiukasti kiinni kielitaitoon liittyvistä

1 joustavuus = kyky sovittaa sanottavansa tekstilajin, tarkoituksen, vastaanottajan ja tilanteen mukaan (Ykin kriteerit 2003) 
käsityksistään (esim. Ang-Aw \& Goh, 2011; Attali, 2015; Eckes, 2008; Lumley \& McNamara, 1995).

Eri kielen piirteiden arvottaminen näkyy arvioinnissa siten, että jos arvioija pitää esimerkiksi rakennetta kielitaidon selkärankana, hän todennäköisesti kiinnittää huomionsa myös oppijan tuotoksessa rakenteiden tarkkuuteen ja perustaa arvionsa tämän kriteerin hallintaan. Tarnanen (2002, s. 265) havaitsi tutkiessaan Ykin arvioijien käsityksiä kirjoittamisen taidosta, että yksittäisten kielen piirteiden painotus näkyi arvioinnissa etenkin silloin, kun arvioijan oli vaikea tehdä päätöstä tai kun arvioitava suoritus oli kahden taitotason rajalla. Tällöin yksittäinen kielen piirre ohjasi arvioijaa suuntaamaan arvionsa joko ylös- tai alaspäin.

Arvioijien käsityksiä siitä, mistä piirteistä suullinen kielitaito koostuu, muokkaavat heidän opintonsa ja kokemuksensa erilaisista oppijoista sekä arviointikokemus (ks. esim. Kim, 2015). Myös muunlaiset taustatekijät vaikuttavat käsityksiin oppijan suullista kielitaidosta. Nämä tekijät liittyvät usein oppijan ensikieleen (esim. Winke, Gass \& Myford, 2013), joka voi ilmetä kohdekielessä esimerkiksi vierasperäisenä aksenttina, rakenteina ja sanastona. Myös arvioijan omalla ensikielellä ja puhujan lähtökielen tuttuudella on merkitystä kielitaidosta tehtäviin arvioihin. Tutkimusten mukaan (esim. Johnson \& Lim, 2009; Kim, 2009; Shi, 2001) äidinkielisten ja ei-äidinkielisten arvioijien arviointilinjat eroavat toisistaan, koska taustaltaan eri äidinkieliset arvioijat painottavat arvioinnissaan eri kielen piirteitä (esim. Kim, 2009). Mitä pienempi etäisyys oppijan lähtökielellä ja kohdekielellä tai arvioijan äidinkielellä on, sitä todennäköisemmin se vaikuttaa arviointiin positiivisesti (Hamp-Lyons \& Davies, 2008). Kuulijalle tutulla aksentilla tuotettua puhetta on helpompi kuunnella ja ymmärtää, koska vieras aksentti vaatii kuuntelijalta totuttautu- mista oppijan tapaan puhua (Carey, Mannel \& Dunn, 2011; Gass \& Varonis, 1984). Lisäksi on todettu arviointia ohjaavan myös arviointikriteereiden ulkopuoliset tekijät, kuten oppijan ääni tai puhetuotoksen sisältö (May 2006; Orr, 2002; Sato 2011).

Vaikka arvioijien toimintaa ohjaavat vakiintuneetkin käsitykset kielitaidon kannalta keskeisistä piirteistä, edellä esitetyt tutkimustulokset kuvastavat hyvin arviointiprosessin monisäkeistä ja vuorovaikutuksellista luonnetta. Arviointiin liittyvät kielitaitokäsitykset ovatkin tavallisesti enemmän dynaamisia, muuttuvia ja kontekstuaalisia kuin stabiileja ja pysyviä (Barcelos \& Kalaja, 2011; Kalaja \& Barcelos, 2003; Mercer, 2011). Tästä syystä on tärkeää, että arvioija myös itse tarkkailee omaa arviointikäyttäytymistään ja tulee siitä tietoiseksi reflektoimalla (Woods \& 冈akir, 2011). Oman ajattelun, käsitysten kielentämisen ja toiminnan suhde ei kuitenkaan ole yksinkertainen ja suoraviivainen prosessi ( $\mathrm{Ne}$ gueruela-Azarola, 2011), sillä vaikka yksilö itse tiedostaa omat käsityksensä, hän saattaa kuitenkin toimia niiden vastaisesti (Woods, 2003, s. 207.) Tämä johtuu siitä, että käsitykset muodostavat monimutkaisen järjestelmän, joiden syntyyn ja muokkaantumiseen osallistuvat muut ihmiset, sosiokulttuurinen ympäristö ja yksilön henkilökohtaiset kokemukset ja historia (Barcelos, 2003; Mercer, 2011; Peng, 2011).

Arvioinnin näkökulmasta ongelmallisia ovat käsitykset, joista emme ole tietoisia (Salo, 2009) ja joihin liittyy voimakkaita affektiivisia piirteitä, tunteita ja arvottamista (Aragão, 2011). Arviointiprosessin aikana voi olla vaikea tunnistaa arviointiin vaikuttavia tunteita tai stereotyyppisiä käsityksiä erilaisista oppijoista. Oppijan tapa puhua kohdekieltä tai tunnistettava aksentti voivat vaikuttaa siihen, miten sujuvasti ja ymmärrettävästi oppija meistä tuottaa kohdekieltä. Oppijan ensikieleen linkittyy kielitaidon li- 
säksi muitakin käsityksiä oppijasta (Munro \& Derwing, 1995, s. 91), koska kielitaidon sosiaalisen luonteen vuoksi aksentti herättää kuulijassa myös assosiaatioita puhujan kuulumisesta tiettyyn sukupuoleen ja etniseen tai sosiaaliseen ryhmään (Giles \& Rakić, 2014).

\section{PUHUJAN ENSIKIELEN TUTTUUDEN VAIKUTUS SUULLISEN KIELITAIDON ARVIOINTIIN}

Suullinen kielitaito voi paljastaa oppijan ensikielen, sillä vain harvat toisen kielen oppijat saavuttavat kohdekielisen ääntämisen ja puhetavan. Vierasperäisyyden tunnistaa puheesta vielä useiden vuosien jälkeen, vaikka oppijat olisivatkin käyttäneet kohdekieltä aktiivisesti päivittäin. (Mora \& Darcy, 2017.) Ykin arvioijat ovat kokeneina S2-opettajina tottuneet ymmärtämään eri aksentilla tuotettua suomea, mutta heidän kokemuksensa eri ensikielen puhujista vaihtelevat. Arvioijat asuvat eri puolilla Suomea, ja Suomessa asuvien vieraskielisten sijoittuminen Suomessa vaihtelee alueittain (SVT, 2018). Arvioijan asuinpaikalla onkin merkitystä sille, mitkä ensikielen ryhmät ovat arvioijille tuttuja.

Arvioijan kokemus erilaista oppijoista on merkittävä tekijä määriteltäessä oppijan kielitaitoa (esim. Gass \& Varonis, 1984; Winke ym., 2013). Mitä tutumpi aksentti ja puhetapa oppijalla on, sitä todennäköisemmin hän saa parempia arvioita kielitaidostaan kuin sellainen oppija, jota arvioija ei ole tottunut kuuntelemaan. Tuttuuden on todettu vaikuttavan ennen kaikkea ääntämisestä ja rakenteellisesta tarkkuudesta annettaviin arvioihin (Carey ym., 2011; Gass \& Varonis, 1984). Kun oppijan puhetapa on tuttu, arvioija ei pidä puheen aksenttia niin vahvana kuin sellainen, jolle puhujan aksentti on vieras (Kang \& Rubin, 2009). Myös jos arvioijalla on tietoa kohdekielen morfologiasta, hänen on helpompi ymmärtää oppijan tuotoksessa olevia puutteita (Ahola, 2020).

Tuttuus vaikuttaa arviointiin ennen kaikkea tuotoksen ymmärrettävyyden kautta (esim. Browne \& Fulcher, 2017, s. 38), mutta ymmärrettävyys kielen piirteenä on varsin monisyinen, ja siihen yhdistyvät useat muut kielen piirteet. Ymmärrettävyys on usein linkittynyt sujuvuuteen (Derwing \& Munro, 1997), ja sujuvuus taas muodostuu useista eri kielen piirteistä, kuten rakenteiden ja sanaston hallinnasta ja koherenssista sekä ääntämisestä (Kormos \& Dénes, 2004). Vieraskieliseen aksenttiin tottuminen on suhteellisen nopea prosessi ja sitä voidaan opetella, minkä jälkeen aksentti ei enää aiheuta suuria ongelmia kielellisessä vuorovaikutuksessa (Ballard \& Winke, 2017; Leinonen, 2015). Puheen ymmärrettävyyttä helpottaa myös se, jos kuulijalle ovat puheenaihe ja puhetilanteen konteksti tuttuja (Kennedy \& Trofimovich, 2008; Gass \& Varonis, 1984).

Yleensä tuttuus yhdistetään positiivisiin käsityksiin oppijan taidosta, mutta tuttuus voi herättää negatiivisiakin tuntemuksia ja mielikuvia puhujista sen mukaan, millaisia kokemuksia arvioijilla on kyseisen kielen edustajista (Browne \& Fulcher, 2017; Lindemann, 2017). Kieliin yhdistyy arvottamista ja stereotyyppisiä käsityksiä kielen puhujista (Major, Fitzmaurice, Bunta \& Balasubramanian, 2002). Tietyt kielelliset piirteet ovat usein puheessa varsin vakiintuneita saman kielen puhujien keskuudessa ja niiden perustella oppijat määritellään myös usein kuuluvaksi tiettyyn kieliryhmään. Tämänkaltaiset stereotyyppiset käsitykset voivat olla jopa niin voimakkaita, että kun puhetta arvioivalle kerrotaan puhujan edustavan tiettyä ensikieltä, arvioija myös kuulee tämän ensikielen piirteitä puheesta, vaikka ensikieli olisikin jokin muu.(Kang \& Rubin, 2009). 


\section{AINEISTO JA MENETELMÄT}

Tämä thainkielisiin suomenoppijoihin liittyvä artikkeli kuuluu Rikkinäistä suomea - Aksenttien arviointi yhteiskunnallisena portinvartijana -tutkimushankkeeseen, jossa tutkitaan viiden ensikielen puhujaryhmän (venäjä, arabia, suomenruotsi, viro ja thai) vieraskielisen aksentin vaikutusta suomen kielen suullisesta taidosta annettaviin arvioihin. Thainkielisiä hankkeeseen osallistui kymmenen henkilöä, joista miehiä oli kaksi ja loput kahdeksan naisia. Thainkielisten sukupuolijakauma poikkesi muista tutkimukseen osallistuneista ensikieliryhmistä, joissa miehiä ja naisia oli saman verran ( 5 miestä ja 5 naista). Thainkielisistä suurin osa oli naisia ( 8 naista ja 2 mistä), koska pääosa Yleisten kielitutkintojen testiin osallistuneista thainkielisistä on myös naisia (96 \% vuosina 2012-2017). Tutkimusluvan antaneet thainkieliset osallistuivat Ykin suomen kielen tutkintoon vuonna 2015 , ja tutkimukseen valittiin ensikielen edustajiksi sellaiset henkilöt, jotka saivat puhumisen suorituksesta joko taitotason 3 $(\sim \mathrm{B} 1)$ tai $4(\sim \mathrm{B} 1)$. Keskitason testistä voi saada myös arvion <3 (alle 3), mutta tämän arvion saaneet jätettiin tutkimuksen ulkopuolelle, koska arvio $<3$ voi tarkoittaa taitotasoa $2(\sim \mathrm{A} 2)$ tai taitotasoa $1(\sim \mathrm{A} 1)$. Kielitaitotason rajaamisella varmistettiin myös se, että tutkimukseen osallistuneiden kielitaito oli sellaisella taitotasolla, että oppijat kykenivät itsenäisesti tuottamaan riittävästi puhetta arviointia varten.

Oppijoiden 11/2 minuuttia kestävän puhesuorituksen arvioi 44 vapaaehtoisesti tutkimukseen osallistunutta Ykin suomen kielen arvioijaa, jotka on merkitty Opetushallituksen viralliseen Ykin arvioijarekisteriin (Finlex, 2004). Rekisteröinti edellyttää arvioijilta opintoja arvioitavasta kielestä, joten kaikilla arvioijilla oli yliopistotutkinto suomen kielestä tai/ja suomi toisena ja vieraana kielenä op- piaineesta. Tutkimukseen osallistuneet arvioijat olivat eri-ikäisiä (31-68 v.) S2-opettajia, jotka olivat toimineet opettajina $8-40$ vuotta ja työskentelivät kotoutumiskoulutusta tarjoavassa oppilaitoksessa (30\%), ammattioppilaitoksessa tai lukiossa (16\%), korkeakoulujen kielikeskuksessa (16\%), valmentavassa koulutuksessa (14\%), perusopetuksessa (9 \%) tai vapaan sivistystyön oppilaitoksessa (9 $\%)$. Heidän kokemuksensa arvioinnista Yleisissä kielitutkinnoissa vaihteli; osa arvioijista on ollut mukana Ykin alkuajoista, vuodesta 1994 lähtien, ja vähiten kokemusta omaavat olivat toimineet arvioijina vasta vuoden.

Arviointiasteikkona käytettiin arvioijille tuttua Ykin 6-portaista arviointiasteikkoa (1-6), joka on linkitetty yleiseurooppalaiseen viitekehykseen seuraavasti: 1 A1, 2 A2, 3 B1, 4 B2, 5 C1, 6 C2. Kukin oppija sai suorituksestaan arvion holistisesti (kokonaisvaltaisesti) kielitaitoa kuvaavan yleiskriteerin lisäksi kuudesta eri kielen piirteistä koostuvasta analyyttisista kriteereistä: sujuvuus, joustavuus, koherenssi/sidosteisuus, ilmaisun tarkkuus/laajuus/idiomaattisuus, ääntäminen/ fonologinen hallinta ja rakenteiden tarkkuus.

Suoritukset arvioitiin kotona sitä varten laaditun sähköisen verkkolomakkeen avulla, jossa kullekin oppijalle annettiin yleiskriteeristä ja jokaisesta kuudesta analyyttisesta kriteeristä taitotasoarvio asteikolla 1-6 (A1-C1). Arvioijien oli myös mahdollisuus halutessaan kirjoittaa arviointien alla olevaan tekstilaatikkoon perustelunsa antamalleen taitotasoarvioille tai muut huomionsa oppijasta. Lisäksi lomakkeessa pyydettiin arvioijia vastaamaan kirjallisesti kysymykseen: minkä oletat olevan puhujan ensi-/lähtökieli ja valitsemaan neliportaisesta Likert-asteikosta (melko epävarma - epävarma - varma - melko varma) ensikielen tunnistamisen varmuusaste sekä kirjoittamaan tekstilaatikkoon perustelunsa oletukselleen oppijan ensi-/lähtökielestä. 
Artikkelini aineisto koostuu siis sekä määrällisestä että laadullisesta aineistosta, mutta se on pääosin laadullista: arvioijien kirjoittamia oppijan ensikielen tunnistamiseen ja taitotasoarvioihin tai yleensä puhujaan liittyviä huomioita. Laadullisen aineiston analyysissa hyödynsin teoriaohjautuvaa sisällönanalyysia, jonka avulla aineisto oli mahdollista saada tiivistettyä sellaiseen muotoon, että tutkittava ilmiötä voitiin kuvailla lyhyesti ja yleistävästi ja etsiä selityksiä tutkittavien ilmiöiden välille. Analyysi eteni osin aineistolähtöisesti ja osin aiempien tutkimusten ja kirjallisuuden pohjalta muodostuneiden ajattelumallien avulla. Aineiston luokittelun ja teemoittelun lähtökohtana oli etsiä aineistosta samankaltaisuuksia ja/tai eroavaisuuksia arvioijien kielitaitoon liittyvistä huomioista. Sitä kautta oli mahdollista käsitteellistää löydetyt teemat, yhdistää ne teoreettiseen tietoon ja aikaisempiin tutkimuksiin sekä keskusteluttaa aineistoa arvioijia ympäröivien diskurssien kanssa, jotka linkittyivät yhteiskunnallisiin, sosiaalisiin, kulttuurisiin ja historiallisiin konteksteihin. (Mayring 2014; Schreier, 2014; Tuomi \& Sarajärvi, 2009.)

Ensikielen tunnistamiseen liittyvä määrällinen aineisto on analysoitu Rikkinäistä suomea-hankkeessa ${ }^{2}$. Analyyseissa tarkasteltiin oppijan ensikielen, sen tunnistamisen ja eri kielellisten piirteiden yhdysvaikutusta. Analyysissa käytettiin Facets-ohjelmaa (Linacre, 2009), joka perustuu Raschin mallin laajennukselle, MFRM-mallille (Many-Facets Rasch Measurement). Analyyseissä hyödynnettiin skaalamuuttujamallilla (Rating scale model) saatuja bias-analyyseja, joiden avulla tarkasteltiin, vaikuttiko arviointikriteereiden käyttöön oppijan ensikieli ja sen tunnistaminen (ks. KUVIO 1).

2 Rikkinäistä suomea-Aksenttien arviointi yhteiskunnallisena portinvartijana -tutkimushankkeen tilastolliset analyysit Reeta Neittaanmäki 


\section{TULOKSET}

Rikkinäistä suomea - Aksenttien arviointiyhteiskunnallisena portinvartijana -tutkimushankkeessa tehtyjen tilastollisten analyysien perusteella (KUVIO 1) arvioijakäyttäytyminen vaihteli, kun arvioijat tunnistivat oppijan ensikielen. Tämä näkyi siten, että arvioijat käyttivät arviointikriteereitä eri tavalla tunnistettuien ia ei-tunnistettuien kohdalla.
Kuviossa 1 on kuvattu arvioijakäyttäytymiseen liittyvää biasia, jonka suuruutta testataan $\mathrm{t}$-testillä: nollaa suuremmat $\mathrm{t}$-arvot kertovat siitä, että havaitut arvot ovat suurempia kuin malli odottaa (viittaavat arvioijien lempeyteen), ja vastaavasti nollaa pienemmät arvot ovat matalampia kuin malli odottaa (viittaavat arvioijien ankaruuteen).

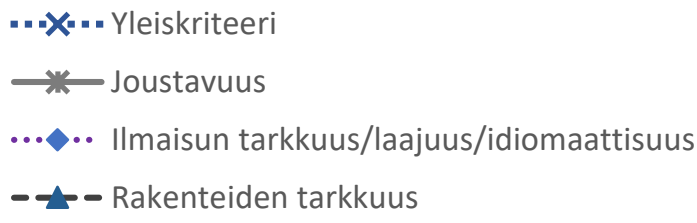

EI TUNNISTETA

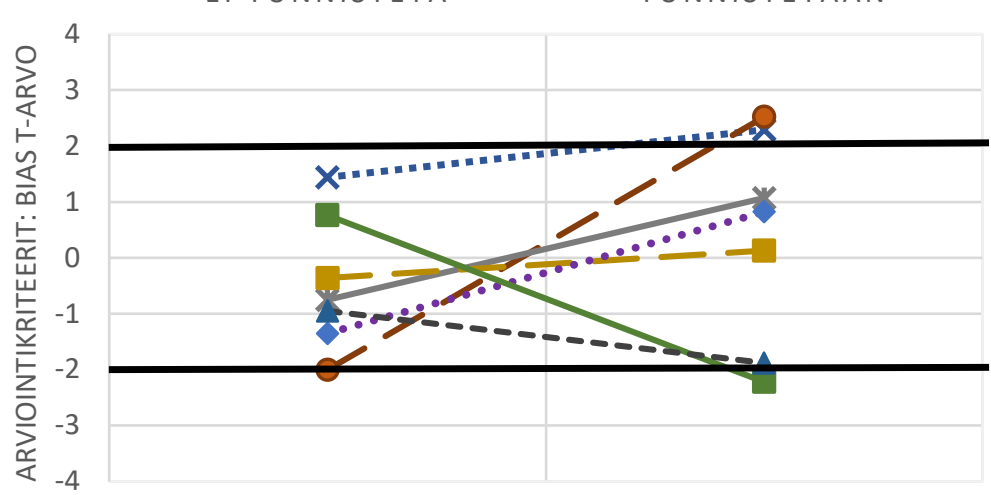

KUVIO 1. Arviointikriteereiden käyttö arvioitaessa ei-tunnistettuja ja tunnistettuja.

Tilastollisesti t-arvot ovat merkitseviä (merkitsevyystasolla 0.05 ), jos ne ylittävät tai alittavat raja-arvot -2-2 (mustat poikkiviivat). Näiden raja-arvojen sisäpuolelle jääneitä kriteereitä arvioijat käyttivät samalla tavalla riippumatta siitä, tunnistivatko he oppijan ensikielen vai ei, mutta raja-arvojen ulkopuolelle jääneet kriteerit näyttäytyvät tilastollisesti merkitsevinä. Tulosten mukaan arviointikäyttäytymisessä oli poikkeamaa kolmen analyyttisen kriteerin kohdalla, jotka jäivät joko raja-arvojen ylä- tai alapuolelle. Ääntämisen ja fonologisen hallinnan $(t=-2,2 ; p=0,03$; d. $f=246)$ taitotasoarvioihin tunnistaminen vaikutti taitotasoarvioita alentavasti, kun taas sujuvuudesta $(t=2,5 ; p=0,01 ; d . f=242)$ ja yleiskriteeristä $(t=2,3 ; p=0,02 ; d . f=236)$ arvioijat palkitsivat thainkieliseksi tunnistettuja. Myös rakenteiden tarkkuuden arvioihin tunnistaminen vaikutti alentavasti, vaikkakin sen $\mathrm{t}$-arvo jää hieman alle merkitsevyysrajan ( $\mathrm{t}$ $=-1,9 \mathrm{p}=0,06 ; \mathrm{d} \cdot \mathrm{f}=246$ ).

\section{1 Thainkielisten oppijoiden vaikeudet suomen kielessä}

Aiemmin jo mainittiin, että tuttuus (esim. Carey ym., 2011; Gass \& Varonius, 1984) vaikuttaa yleensä positiivisesti ääntämisen ja fonologisen hallinnan kriteeristä annettavaan 
taitotasoarvioon. Thainkielisten kohdalla tulokset kuitenkin olivat erilaisia, sillä kuten kuviosta 1. on havaittavissa, thainkieliseksi tunnistetuilla ääntämistä ja fonologista hallintaa pidettiin heikoimpana taitona.

Thainkielisiä osallistuu Ykin suomen kielen tutkintoihin vuosittain n.100 henkilöä, joten usealla arvioijalla on karttunut kokemusta thainkielisten arvioinnista. Aksentin tuttuutta tukee myös se, että arvioijat tunnistivat oppijoiden ensikielen varsin hyvin; yli $70 \%$ arvioijista tunnisti tutkimukseen osallistuneiden thainkielisten naisten $(\mathrm{n}=8)$ ensikielen, vain miehet $(n=2)$ tunnistettiin heikosti. Kirjallisissa huomioissaan arvioijat analysoivat varsin monisanaisesti thainkielisten oppijoiden ääntämiseen liittyviä piirteitä. Yksittäisistä äänteistä arvioijat pitivät helpoiten tunnistettavana piirteenä suomen kielen $r$-äännettä, jota pidettiin suomalaiseksi liian pehmeänä tai välillä se jätettiin kokonaan ääntämättä tai se korvattiin $l$-äänteellä (esim. ruokaa = "luokaa"). Lisäksi thainkieliset tunnistettiin vaikeuksista ääntää konsonanttiyhtymät $-t s$ - ja $-s t$ - (kutsu $=" k u s s u "$, itse $=$ "isse", keskustella = "keskuttella", matkustaminen= "matkuttamine"). Muutamat arvioijat olivat myös huomioineet sananloppuisen $s$-äänteen poisjäämisen tai sen korvaamisen $t$-äänteellä (joskus= "josku", "joskut") ja suomalaisen $v$ äänteen korvaamisen thain puolivokaalilla $w$ ("kiwa", "juttelewat,"'wiikossa"). Vokaaleista arvioijat mainitsivat vokaalit $y, u$ ja $\ddot{a}$, joiden ääntäminen ei arvioijista aina onnistunut kohdekielen mukaisesti. Nämä samat edellä mainitut fonologiset vaikeudet ovat myös Aho ym. (2016) maininneet tyypillisinä ongelmina thainkielisille suomen oppijoille, kun he kuvailivat thain kielen vaikutusta suomen kielen fonologiaa (ks. sivu 3).

Thainkielisten tunnistaminen kertoi siitä, että usealla arvioijalla oli joko opetuksen tai Ykin arvioijana toimimisen kautta käsityksiä thainkielisten suomen ääntämiseen liittyvistä piirteistä. Yksittäisten äänteiden lisäksi kohdekielestä poikkeava prosodia usein paljastaa oppijan ensikielen (Anderson-Hsieh, Johnson \& Koehler, 1992; Giles \& Rakić, 2014), ja myös arvioijat tunnistivat thainkieliset suomen kielestä poikkeavasta puherytmistä ja intonaatiosta:

(1) Puhe on nasaalimaista ja venytettyä.

(2) "Naukuva" nuotti, intonaatio.

(3) Nasaalimainen, korkea ja etenkin jälkitavuja venyttävä sävelkulku.

(4) Intonaatio, puherytmi ja tauotus tuntuvat aasialaiselta.

(5) Puheen rytmi, intonaatio ja fonologia kauttaaltaan kuulostaa aasialaiselta.

Thainaisten puhetta kuvailtiin ilmaisulla "naukuva", joka suomen kielessä voi jossain yhteydessä kantaa negatiivista merkitystäkin. Ilmaisulla arvioijat kuitenkin viittasivat puheen intonaatioon ja nasaaliin äänenlaatuun; puheessa oli "notkuva" aasialainen intonaatio", jota korosti "aasialaisen korkealla tasolla" oleva äänenkorkeus. Huomiossa tällainen puhetyyli yhdistettiin myös lapsen tai nuoren tapaan puhua. Kuten seuraavista esimerkeistä on havaittavissa, arvioijien kirjoittamiin huomioihin liittyy myös arvottavaa sävyä, ja lisäksi puhe yhdistettiin tiettyyn etniseen taustaan ja stereotyyppisiin mielikuviin puhujien fyysisistä ominaisuuksista ja iästä (esim. Bent \& Holt, 2017).

(6) Tyttömäinen tapa ja intonaatio muistuttavat thainmaalaisia puhujia.

(7) Ääntäminen on myös naiivin kuuloista, kuin pikkulapsen puhetta.

(8) Lapsellisen kuuloista.

(9) Puhuja kuulostaa pienikokoiselta ja jopa vähän lapsekkaalta. 
Äänenkorkeus ja siihen liittyvät käsitykset ovat varsin kulttuurisidonnaisia, koska eri kulttuureissa äänen korkeuteen liittyy erilaisia arvostuksia ja stereotypioita. Suomessa naisilla on tavallisesti matalampi puheääni kuin esimerkiksi aasialaisilla naisilla, ja matalaa ääntä pidetään meillä tavallisesti miellyttävämpänä ja sosiokulttuurisesti tavoiteltavampana ominaisuutena kuin liian korkeaa puheääntä. Aasiassa puolestaan korkea puheääni on liitetty naisen kulttuurisiin ominaisuuksiin (Ketolainen, Laakso \& Simberg, 2017; Leino, Laukkanen, Ilomäki \& Mäki, 2008). Arvioijien mainitsema äänenkorkeus on ehkä yleisestikin tyypillisin piirre, johon suomalaiset kiinnittävät huomiota kuullessaan thainkielisten tai yleensä aasialaisten puhuvan.

Arvioijien viittaukset lapsenomaisuuteen olivat todennäköisesti yhteydessä siihen, että thainkielisten useat foneettiset piirteet suomessa ovat lapsen kielen kaltaisia, esimerkiksi vaikeudet ääntää apikaalinen $r$-äänne. Mutta huomioissa arvioijat toivat myös esiin työkokemuksensa ja yhteiskunnassa käytyjen keskustelujen kautta kertynyttä tietämystään siitä, keitä thainkieliset oppijat Suomessa ovat: nuoria naisia, jotka ovat tulleet Suomeen avioliiton kautta.

(10) Suomalaisilla miehillä on paljon nuoria thai-vaimoja.

(11) Thaimaalaisia puolisoita on Suomessa aika paljon, ja kuulostaa suomalaisen puolison vaimolta (käy kalastamassa, saunassa ym.)

(12) Voisi olla suomalaismiehen thaimaalaisvaimo.

Arvioijien käsityksiä thaimaalaisista nuorina naisina tukevat viralliset väestötilastot Suomessa. Kaikista thainkielisistä naisten osuus on $83 \%$ ja suurin osa thainaisista on alle 45-vuotiaita naisia (70 \%) (SVT, 2018). Thainkielisyyden liittämistä ennen kaikkea naispuolisiin puhujiin tuki myös thainkielisten miesten heikko tunnistaminen, sillä kahta tutkimukseen osallistunutta thaimiestä arvioijat eivät tunnistaneet thainkielisiksi. Ensimmäistä miestä ei kukaan tunnistanut thainkieliseksi ja toisen miehen kohdalla n. 7 $\%$ arvioijista osasi mainita oikean ensikielen. Yksi syy heikkoon tunnistamiseen oli mahdollisesti se, että arvioijilla ei ollut kokemusta nuorten, alle 25-vuotiaiden thainkielisten miesten opettamisesta ja he eivät olleet kuulleet thainkielisten miesten puhuvan suomea. Kokemuksen puutetta tukee myös se, että arvioijat opettavat pääasiassa aikuisia maahanmuuttajia ja taas Suomessa thainkielisistä miehistä $(\mathrm{N}=1600)$ yli $60 \%$ on alle 25 -vuotiaita nuoria ja lapsia (SVT, 2018).

Toinen syy tunnistamisvaikeuksiin liittyy miesten kielitaitoon, ennen kaikkea ääntämiseen ja fonologiseen hallintaan. Arvioijien mielestä thaimiehillä oli varsin kohdekielinen ääntäminen, vaikka muuten heidän tuotoksissaan esiintyi paljon puutteita. Hyvän ääntämisen takia arvioijat eivät selvästikään osanneet yhdistää heitä thainkieliseksi, ja he eivät myöskään huomioineet tuotoksissa heille tuttuja thainkielisten oppijoiden lähdekielisiä piirteitä. Arvioijista thaimiesten tuotoksista oli "hyvin vaikea tunnistaa mitään tiettyä lähtökieltäpuheen taustalta”, koska puhujat olivat heistä nuoria: "tämä nuori on asunut kauan suomen kielen alueella ja käynyt kouluaan täällä ja hänellä on kavereita, joiden kanssa bän on tottunut pubumaan sujuvasti suomea". Käsitykset iän merkityksestä kieltenoppimiseen ovat yhteydessä arvioijien koulutuksen ja työkokemuksen kautta omaksuttuun tietoon siitä, että yleensä lapset ja nuoret oppivat kielen helpommin, ja arvioijien mielestä se näkyi näiden miesten kohdalla ennen kaikkea hyvänä kohdekielisenä ääntämisenä. Mitä myöhemmällä iällä toisen kielen oppiminen on aloitettu, sitä voimakkaampina nähdään myös ensikielen vaikutukset toisessa kielessä (Bent \& Holt, 2017). 
Molemmilla miehillä oli arvioijien huomioiden perusteella hyvin "liudentunut l", ja tästä syystä heidän ensikieleksi ehdotettiin venäjää. Venäjän ohessa arvioijat yhdistivät puhujat usein myös ensikielenään somalia tai arabiaa puhuviin, mikä on ehkä yhteydessä siihen, että arvioijat tietävät arabian- ja somalinkielisiä osallistujia olevan paljon Yki-testeissä ja suurin osa heistä on miehiä: "Näitä kieliä on ykiläisten äidinkielenä paljon, siksi helppo arvata (arabia)"; "En ole itse koskaan opettanut somaleita enkä tunne kieltä, mutta jotenkin tämä kuulosti siltä". Huomiot liudentuneesta $l$-äänteestä ja viittaukset Ykin osallistujien taustojen tuntemisesta kuvastavat sitä, miten suullisessa kielitaidossa käsityksiin oppijan ensikielestä vaikuttavat pienetkin kielelliset vihjeet ja taustatiedot, joiden avulla oppijat assosioidaan jonkin kieliryhmittymän edustajaksi (Kang \& Rubin, 2009).

Ensikielen tunnistaminen yhdistyi arvioijien huomioissa käsityksiin thainkielisten heikosta ääntämisen ja fonologian hallinnasta ja vaikeuksista oppia ääntämään suomea.

(13) Thainmaalaisilla puheen tuottaminen tuntuu olevan raskasta. Paino on usein joka sanalla tai yksittäisissä sanoissa ja taukoja sanojen välissä.

(14) Lähtökieli kuuluu ääntämisessä vahvasti. Vaatii kuulijalta tarkkaavaisuutta ja kärsivällisyyttä ja puhujalta varmasti toistoa, jotta tulee arkipäivänä ymmärretyksi.

(15) Aasialaisten ääntäminen on tosi erilainen ja heidän on niin kovin vaikea oppia meidän kielemme ääntämistä.

(16) Intonaatio, puherytmi ja tauotus tuntuvat aasialaiselta: Puherytmi ja monotoninen intonaatio sekä jatkuva sanojen ja tavujen painotus alkavat ahdistaa.
Thainkielisten suomen ääntämisen oppimista pidettiin vaikeana lähtökielen vuoksi. Mutta ääntämisen vaikeudet eivät koskettaneet vain oppijoita, vaan thainkielisten ääntäminen vaati myös arvioijista kuuntelijalta ponnisteluja.

Käsityksiä thainkielisten yleisestä heikosta ääntämisen ja fonologian hallinnasta tuotiin esiin myös päinvastaisissa tapauksissa, joissa oppijan ääntämys oli thainkielisyydestä huolimatta arvioijista ymmärrettävää ja siinä oli löydettävissä kohdekielenomaisia piirteitä. Hyvää ääntämystä kuvattiin yllättävänä piirteenä kielitaidossa, vaikka selkeästi puhujan ongelmat rakenteiden tarkkuudessa ja tiettyjen äänteiden ääntämisessä viittasivat aasialaistaustaiseen puhujaan.

(17) Puhujan ääntäminen on yllättävän hyvä, mutta rakenteet todella puutteellisia ja ilmaisun tarkkuus ja koherenssikin alhaisia.

(18) Yllättävästi asiasta saa selvää, vaikka sekä rakenteissa, sanastossa että ääntämisessä on selvästi puutteita.

(19) Selkeä ääntämys vaikka aasialaisuuden kuulee.

Ääntämisen ja fonologisen hallinnan lisäksi tunnistamisella oli vaikutusta rakenteiden tarkkuuden arvioihin (ks. KUVIO 1, s. 9). Vaikka rakenteiden tarkkuus jäi juuri ja juuri t-arvon -2 alle (-1.9), kirjallisissa huomioissa rakenteiden puutteita kuvailtiin usein. Oppijat tekivät arvioijien mukaan liikaa rakenteellisia virheitä ja hallitsivat vain yksinkertaisia rakenteita, minkä vuoksi heidän taitotasoarvionsa rakenteiden tarkkuudesta eivät yltäneet taitotasolle $3(\sim \mathrm{B} 1)$. Rakenteiden tarkkuudella oli myös vaikutusta viestin välittymiseen tai ongelmiin viestin välittymisessä. 
(20) Systemaattisia virheitä perusrakenteissa, viesti kuitenkin tulee selväksi.

(21) Rakenteissa runsaasti puutteita, mutta viesti tulee ihmeen helposti ymmärretyksi.

(22) Puhuu "sanoja peräkkäin". Viesti menee huonosti perille.

Rakenteiden merkitystä osana hyvää kielitaitoa korostivat myös ne arvioijat, jotka yhdistivät heikon rakenteiden tarkkuuden ja informaalin kielen oppimisen toisiinsa.

(23) Kuuntelemalla ja puhumalla kielen oppinut henkilö. Yksinkertaisissakin lauserakenteissa isoa vaihtelua, samoin morfologiassa.

(24) Tuottaa puhetta koko ajan, rakenteissa puutteita. On oppinut kuuntelemalla.

(25) Tyypillinen ko. kielialueen puhuja, joka ei kiinnitä huomiota rakenteisiin yms., mutta on oppinut jonkinlaisen käytännön kielitaidon pääosin arkielämässään.

Huomioillaan arvioijat ilmaisivat arvostustaan formaalia kielenoppimista kohtaan. Ilman formaalia oppimista "kielenoppiminen taitaa olla hidasta ja vaatii paljon aikaa. Koulutustausta?". Arvioijien mukaan puhumalla ja kuuntelemalla hankittu kielitaito riittää arkipäivän kielenkäyttötilanteissa, mutta parempi kielitaito saavutetaan opiskelemalla, mikä vaatii aina työtä ja ponnisteluja. Etenkin rakenteiden tarkkuus paljasti arvioijista sen, miten oppija on kielen oppinut: "Pubuja vaikuttaa siltä, että hän on opiskellut suomen kieltä ja perehtynyt sen kielioppiin. Kuvailee suuntaa, käyttääpostpositioita ja yrittääperustella"; "On selvästi opiskellut ja opetellut suomen kieltä kurssilla". Tämänkaltaiset huomiot viittaavat varsin perinteiseen käsitykseen kielenoppimisesta, joka rakentuu formaalista oppimisesta ja jossa hyvä rakenteiden tarkkuus kertoo kielitaidon hyvyydestä ja heikkoudesta (Saarinen, Kauppinen \& Kangasvieri 2019). Tällaiset käsitykset voivat johtaa myös siihen, että arvioinnissaan arvioijat painottavat rakenteiden tarkkuutta.

\subsection{Thainkielisten oppijoiden vabvuudet suomen kielessä}

Arvioijat palkitsivat thainkielisiä ennen kaikkea sujuvuuden hallinnasta (ks. KUVIO 1, s. 9). Sujuvuus yhdistetään tavallisesti oppijan varsin vaivattoman tuntuisesti ja hyvällä tahdilla tuotettuun puheeseen, jossa ei ole liiaksi häiritseviä taukoja ja korjauksia. Lisäksi sujuva tuotos on rakenteellisesti ja sanastollisesti helposti ymmärrettävää ja sisällöltään koherenttia (esim. Kormos \& Dénes, 2004; Olkkonen \& Peltonen, 2017; myös Yleiset kielitutkinnot, 2003.) Vertailtaessa tätä sujuvuuden kuvausta arvioijien aikaisempiin huomioihin thainkielisten rakenteiden ja ääntämisen puutteista, sujuvuuden arvioissaan he huomioiden perusteella painottivat kykyä tuottaa puhetta aktiivisesti ja täyttää annettu puheaika tuotoksella. Arvioijien mielestä thainkieliset tuottivat paljon puhetta, mikä antoi ehkä positiivisemman kuvan kielitaidosta kuin se tarkemmin tarkasteltuna olikaan.

(26) Puhe on sujuvaa ja tuotosta syntyy suht paljon. Hakee sanoja jonkin verran ja puhe on osittain luettelomaista.

(27) Pintasujuva eli tuottaa runsaasti puhetta, vaikka ei ehkä sano kovin paljon, toistoa siis.

(28) Tuottaa runsaasti sisältöä. Vaikea arvioida - sujuvuuden vaikutelma, mutta paljon horjuntaa. 
(29) Rakenne puutteellinen ja morfologia puuttui lähes kokonaan. Puhujalla oli kuitenkin tahto puhua ja tulla ymmärretyksi, koska hän ei pitänyt taukoja eikä jäänyt korjailemaan puhettaan.

Tuotoksen määrä on yksi sujuvuuden piirteistä, sillä esimerkiksi Fillmore (1979) on todennut sujuvuuden olevan yhteydessä tuotoksen määrään ja siihen, että puhuja täyttää annetun ajan puheella. Sujuvuuden vaikutelmaa thainkielisten tuotoksissa korosti myös se, että heidän todettiin tuottavan puhetta varsin hyvällä puhenopeudella. Kormos ja Dénes (2004) havaitsivat tutkiessaan äidinkielisten ja ei-äidinkielisten kieltenopettajien käsityksiä sujuvuudesta, että opettajat kielitaustasta huolimatta pitivät puhenopeutta ja puheajan täyttämistä yhtenä tärkeimpänä sujuvuuden merkkinä, kun taas esimerkiksi sanaston ja rakenteiden tarkkuus ja taukojen määrän merkitys sujuvuudelle vaihteli opettajakohtaisesti. Arvioijien mielestä thainkieliset olivat yritteliäitä, jotka pyrkivät puhumaan aktiivisesti kielitaidon puutteista huolimatta, vaikkakin puhe muodostui lauseista, joissa sanat olivat perusmuodossa ja tauot lauseiden ja ajatusjaksojen väliltä puuttuivat.

(30) Paljon puhetta yhteen pötköön. Puhe vähän rakenteellisesti pomppivaa.

(31) Verbi puuttuu usein ja ilmaisut rakentuvat peräkkäin pannuista sanoista.

(32) Puhuu yhteen pötköön, tauottamatta asioita loogisiksi kokonaisuuksiksi.

(33) Sanoja peräkkäin perusmuodossa, asia tulee selväksi.

"Yhteen putkeen" tuotettu puhe ei anna hyvää vaikutelmaa kielitaidosta, mutta kirjallisten huomioiden perusteella thainkielisiä palkittiin siitä, että he pyrkivät tuottamaan aina jotain heikosta kielitaidosta huolimatta.
Arvioijien mielestä aktiivisuus riitti joissain tapauksissa kielitaidon osoittamiseen, vaikka oppijoilla oli muissa kielitaidon osa-alueilla vielä puutteita (myös Ang-Aw \& Goh, 2011; May, 2006). Vaikka arvioijista tuotokset koostuivat usein irrallisista sanoista, heidän mielestään oppijat "selviytyvät ilman tarkkuutta ja heikoillakin kielen rakenteilla" ja vaikka "perusrakenteet olivat erittäin puutteelliset, pubuja tulee ymmärretyksi tästä aibeesta, vain pubujan asuinpaikka piti arvata!'. Aktiivisuus selkeästi houkutteli arvioijia antamaan parempia arvioita, ja ilman oman arviointikäyttäytymisen tarkkailua se vaikutti positiivisesti käsityksiin oppijan taidosta: "pubuja yrittää niin pontevasti, että tekisi mieli antaa kolmonenkin, mutta kriteerien perusteella en pysty".

Sujuvuuden lisäksi arvioijat painottivat thainkieliseksi tunnistettujen kohdalla yleiskriteeriä (KUVIO 1, s 10). Tämä oli mielenkiintoinen tulos, koska arvioijien yksittäisistä analyyttistä kriteereistä antamat arviot viittasivat vielä varsin heikkoon kielitaitoon, mutta yleiskriteerillä (sisältää analyyttiset kriteerit) he kuitenkin palkitsivat thainkielisiä. Yleiskriteerin arvio yhdistyi osalla arvioijilla tuotoksen ymmärrettävyyteen, sillä muutamat arvioijat mainitsivat perusteina arviolleen ymmärrettävyyden tai sen puutteen. Ymmärrettävyyttä pidettiin ikään kuin rajapyykkinä perus- ja keskitason kielitaidolle, mutta arvioijat tulkitsivat ymmärrettävyyden eri tavoin. Esimerkkinä tästä alla saman puhujan tuotokseen liittyvät huomiot (suluissa annettu taitotasoarvio).

(34) Paljon epävarmuutta sanastossa ja rakenteissa; sisältö on kuitenkin suurimmaksi osaksi ymmärrettävä. (3)

(35) Tulee ymmärretyksi, vaatii kuulijalta kärsivällisyyttä. (3)

(36) Puhuja yrittää kertoa, mutta kuulijan on vaikea ymmärtää. $(<3)$ 
(37) Puheessa esiintyy paljon virheitä, mutta se on myös sujuva ja hyvin ymmärrettävä. (3)

(38) Kokonaisuus selviää toisella kuuntelemisella. $(<3)$

(39) Ymmärrettävääkin, mutta kuulijan on vaikea hahmottaa puhetta ensikuulemalta. $(<3)$

Arvioijien mielestä thainkielisten puheen ymmärtäminen vaati harjaantumista ja totuttautumista, koska rakenteiden ja sanaston puutteet sekä ääntäminen vaikeuttivat ymmärtämistä. Puheen seuraaminen oli raskasta: "paikoitellen raskasta kuunneltavaa," "pubujaa on melko raskasta kuunnella". Vierasperäisellä korostuksella tuotettua kieltä on usein väsyttävää kuunnella, jos sen ymmärtäminen vaatii enemmän puheen prosessointia (Munro \& Derwing, 1995).

Ymmärrettävyyden korostuminen tasoarvioissa on mielenkiintoista, koska ymmärrettävyys ei ole oma kriteerinsä Ykin arviointia ohjaavissa kriteereissä, vaan se sisältyy useaan muuhun kriteeriin. Gass ja Varonis (1982) yhdistävät ymmärrettävyyteen ennen kaikkea oppijan ääntämisen ja rakenteellisen tarkkuuden, mutta myös esimerkiksi sanastolla ja sujuvuudella sekä koherenssilla on merkitystä ymmärrettävyyteen (Isaacs \& Trofimovich, 2012; Saito, Trofimovich, Isaacs \& Webb, 2017). Arvioijista ymmärrettävyys taas oli huomioiden perusteella yhteydessä ennen kaikkea arkipäiväisissä tilanteissa selviytymiseen: "ymmärrettävä, arkipäivän selviytymistaito"; "Sanasto on suppeaa, konkreettisiin ja jokapäiväisiin tarpeisiin liittyvää, tuotos on kuitenkin ymmärrettävää".

Arkipäivän kielenkäyttötilanteissa selviytymisen rinnalla ymmärrettävyyteen yhdistyi vaikutelma tuotosten sujuvuudesta ja tuotoksen määrä. Useat arvioijat pohtivatkin huomioissaan, voiko thainkielisten hyvin ei-kohde- kielistä puhetta ymmärtää, jos ei ole tottunut heidän puhumaansa suomen kieleen.

(40) Ymmärrän suurimman osan puheen sisällöstä, mutta en ole varma, ymmärtäisikö sellainen henkilö, joka ei ole tottunut kuuntelemaan S2-oppijoiden puhetta.

(41) Puhetta olisi ehkä täysin mahdoton ymmärtää, jollei itsellä olisi ollut thaiopiskelijoita.

Opettajina he olivat tottuneita ymmärtämään oppijoita pientenkin kielellisten vihjeiden perusteella, mutta arvioidessaan he joutuivat huomioimaan myös sen, ymmärtävätkö "tavalliset suomalaiset" epätäydellisesti tuotettua suomea. Eräs arvioija tosin totesi, että nykypäivänä tarvitsee ymmärtää yleissuomesta poikkeavaakin suomea: tämä on minusta sitä uussuomea, joka meidän on vain byväksyttävä arkipäivässä. Rineyn, Tagakin ja Inutsukan (2005) mukaan ymmärrettävyys on kuulijakohtaista ja puhujakohtaista, vaikkakin tietyt kielelliset ongelmat ja aksentin piirteet ovat varsin samankaltaisia samasta kieliyhteisöstä tulevien oppijoiden kesken. Kuulijan ymmärtämistä kuitenkin edesauttaa totuttautuminen oppijan puhetyyliin, mutta se edellyttää ajallisesti ja määrällisesti riittävästi tuotosta (Bradlow \& Bent, 2008, s.708).

Hyviä sujuvuuden ja yleiskriteerin taitotasoarvioita on kuitenkin vaikea perustella yksinomaan arviointia ohjaavien kriteereiden perustella, ja tästä syystä arviointiin ehkä vaikuttivat myös kriteerin ulkopuoliset tekijät, kuten emootiot. Emootiot liittyvät usein oppijan aksenttiin, jonka kautta hänet yhdistetään tiettyyn ensikielenryhmään, ja ensikielen tunnistaminen voi laukaista joko positiivisia tai negatiivisia stereotypioita oppijoita kohtaan (Cargile \& Giles, 1997). Thainkieliseksi tunnistaminen herätti muutamissa arvioijissa myötätuntoa: "Näiden kielten pubujien on niin vaikea oppia, että he eivät ehkä koskaan 
saa nostettua tasoaan ylemmäksi. Tulee sääl”; "Sympaattinen, mutta tolkkua ei oikein ole". Tunteiden lisäksi omat kokemukset thainkielisistä oppijoista herättivät mielikuvia puhujista ja heidän taidostaan: "Ä̈̈nenväri on beleä, kuten kaikilla sieltä olevilla opiskelijoillani"; "Tähän tapaan aasialaiset naisopiskelijani pubuvat", "Muistuttaa niin täydellisesti tällä betkellä luokassani istuvaa opiskelijaa". Varsin tyypillistä kielitaidon arvioinnissa näyttääkin olevan se, että arvioijat vertaavat suorituksia omiin kokemuksiinsa vastaavista oppijoista.

Kriteereiden ulkopuoliset tekijät olivat merkityksellisiä myös tilanteissa, kun oppijan kielitaito oli taitotasojen rajalla. Syntyi vaikutelma siitä, että tällöin arvioijat herkästi nostivat thainkielisten yleiskriteerin taitotasoa ylöspäin, vaikka he havaitsivat suuriakin puutteita oppijan tuotoksessa.

(42) Hän selviytyy kertomuksestaan, joten siksi annan (heikon) kolmosen, vaikka tuotoksessa on paljon "kauneusvirheitä”. (arvio 3)

(43) Kakkosen ja kolmosen rajalla, sujuvaa ja aiheessa pysyvää, mutta ääntäminen ja rakenteiden hallinta vielä enemmän kakkosen puolella (arvio 3).

(44) Äänteelliset ongelmat ja toistuvat rakenteet tässä vetäisivät alle kolmosen. (arvio 3)

Vaikuttaakin siltä, että arvioijien käsitykset ensikielen vaikutuksista suomen oppimiseen ovat yhteydessä arviointikäyttäytymiseen. Koska suomen oppimista pidetään thainkielisille hyvin vaikeana, ei heidän kielitaidolleen aseteta yhtä suuria vaatimuksia kuin esimerkiksi vironkielisille, joiden kielitaidolle asetettiin selkeästi korkeammat vaatimukset lähikielisyyden vuoksi (Ahola, 2020).

\section{LOPUKSI}

Arvioijat tunnistivat thainkielisten naisten ensikielen helposti, mutta thainkielisten miesten ensikieli tunnistettiin huonosti. Tunnistamisella oli yhteys annettuihin taitotasoarvioihin, ja se näkyi ennen kaikkea tiettyjen yksittäisten analyyttisen arviointikriteereiden kohdalla. Thainkielisiksi tunnistettujen kielitaidon heikkouksina arvioijat mainitsivat ennen kaikkea vaikeudet ääntää suomea ja puutteet rakenteiden käytössä. Kielitaidon vahvuuksina taas pidettiin sujuvuutta ja selviämistä heikollakin kielitaidolla ymmärrettävästi arkipäiväisissä kielenkäyttötilanteissa, mikä vaikutti yleiskriteeristä annettuihin taitotasoarvioihin.

Thainkieliseksi tunnistettujen kielitaitoon liittyvistä käsityksistä vahvimpana nousi esiin suomen kielen ääntämisen ja fonologian heikko hallinta. Arvioijat tunnistivat thainkieliset ääntämisen puutteista, mikä kertoo siitä, että arvioijilla on oman opetuskokemuksen tai Ykin arviointikokemuksen kautta muodostuneita käsityksiä thainkielisille oppijoille vaikeuksia tuottavista piirteistä suomen kielen ääntämisessä. Syitä ääntämisvaikeuksiin etsittiin lähtö- ja kohdekielen eroista, jotka näkyivät etenkin ongelmina tiettyjen äänteiden tuottamisessa, mutta myös kohdekielestä poikkeavana puherytminä ja intonaationa. Ääntämisvaikeuksien takia thainkielisten puheen ymmärtäminen edellytti arvioijista tottumusta aasialaisella aksentilla tuotetusta puheesta. Lisäksi he pitivät thainkielisten tuotosten kuuntelemista raskaana, koska ymmärtäminen vaati paljon tulkintaa. Arvioijien käsityksissä suomen kohdekielinen ääntäminen oli thainkielisille taito, jonka saavuttaminen vaatii oppijoilta suuria ponnisteluja.

Rakenteiden tarkkuuden arvostus kielitaidossa näkyi kirjallisissa huomioissa, sillä arvioijat viittasivat niissä usein rakenteisiin liittyviin puutteisiin. Käsitykset rakenteiden 
tarkkuuden tärkeydestä kielitaidossa ovat todennäköisesti yhteydessä arvioijien päivätyöhön, jossa he opettajina ovat tottuneita huomioimaan tuotoksissa esiintyviä puutteita. Puutteet rakenteissa vaikuttivat arvioijista ennen kaikkea tuotoksen viestittävyyteen ja ymmärrettävyyteen. Rakenteiden hallintaan liittyi myös käsityksiä siitä, miten kieltä opitaan parhaiten. Arkipäivässä puhumalla tai kuuntelemalla opittu kieli ei arvioijista aina kehity rakenteelliselta tarkkuudeltaan samalle tasolle kuin formaalin kielenoppimisen avulla omaksuttu kielitaito.

Arvioijien kirjallisissa huomioissa nousi esiin myös thainkielisten yritteliäisyys puhua suomea, mikä näkyi etenkin hyvinä sujuvuuden kriteerin taitotasoarvioina. Vaikka sujuvuuteen vaikuttavat eri kielen piirteiden hallinta, arvioijien käsityksissä sujuvuuden kriteeri yhdistyi ennen kaikkea thainkielisten tapa tuottaa puhetta ilman taukoja ja täyttää annettu puheaika puheella. Arvioijat huomioivat thainkielisten kielitaidon heikkoudet, mutta heidän aktiivisuutensa tuottaa puhetta loi mielikuvan puhujista, jotka pärjäävät arkipäivän kielenkäyttötilanteissa puutteellisellakin kielitaidolla.

Yleiskriteerin kohdalla ymmärrettävyys nousi tärkeäksi kielitaidon piirteeksi. Ymmärrettävyyttä pidettiin eräänlaisena kriteerinä riittävälle ja ei-riittävälle kielitaidolle, vaikka tuotosten ymmärrettävyydestä arvioijat eivät olleet aina samaa mieltä. Tämä todistaa sitä, että ymmärtäminen on hyvin kuulijakohtaista ja tilanteesta riippuvaa. Yleiskriteerin käyttö viesti myös siitä, että arviointiin liittyi subjektiivisia, kriteereiden ulkopuolisia tekijöitä. Etenkin oppijan taidon ollessa kahden taitotason rajalla, arvioijat "palkitsivat" oppijaa analyyttisia kriteereitä paremmalla yleiskriteerin taitotasoarviolla. Arviointikäyttäytymiseen vaikuttivat tällöin todennäköisesti työ- tai arviointikokemuksen kautta muodostuneet tunneperäiset kokemukset thainkie- lisistä suomen kielen käyttäjinä ja oppijoina ja ympäröivästä yhteiskunnasta kumpuavat käsitykset thainkielisistä Suomessa.

Kriteereiden ulkopuolisten tekijöiden merkitystä arvioinnissa vahvistavat myös arvioijien ei-tunnistettuihin thaimiehiin liittyvät huomiot. Arvioijat tulkitsivat heidän olevan arabian-, somali- ja venäjänkielisiä oppijoita, ja tästä syystä he myös kuulivat näille ensikielelle tyypillisiä piirteitä oppijoiden puheessa. Tämä antaa viitteitä siitä, että arvioinnissa pienilläkin kielellisillä vihjeillä on merkitystä sille, millaisia käsityksiä arviointitilanteessa oppijasta ja oppijan kielitaidosta muodostetaan. Arvioijakoulutuksessa ja arvioijille annettavassa palautteessa onkin tärkeä saada arvioijat tunnistamaan omat eri ensikielitaustaisiin oppijoihin liittyvät käsitykset ja stereotyyppiset ajattelumallit, koska tietoisuus auttaa arvioijia havainnoimaan omaa arviointikäyttäytymistään.

Artikkeli osoittaa, että ensikielen tunnistaminen herättää arvioijissa työ- ja opiskelukokemuksen sekä sosiokulttuurisen ympäristön ja yhteiskunnan kautta muodostuneita käsityksiä oppijoista ja heidän kielitaidostaan. Tuloksia tulkittaessa on kuitenkin hyvä huomioida tutkimusasetelma, jossa arvioijia pyydettiin tunnistamaan oppijoiden ensikieli. Tunnistamisen vaatimuksella oli merkitystä sille, että arvioijat huomioivat oppijoiden ei-kohdekieliset piirteet ja puutteet kielitaidossa, mutta myös aidossa arviointitilanteessa arvioijien on todettu havainnoivan näitä samoja piirteitä tuotoksista ja tunnistavan usein oppijan ensikielen (Carey ym. 2010; Munro\& Derwing 1995).

Tutkimusasetelman lisäksi oma asemani arvioijien kouluttajana on edellyttänyt tulkintojen reflektointia. Olen pyrkinyt tulosten analyysissa ja tulkinnassa objektiivisuuteen teemoittelemalla aineistoa ja tukeutumalla laadullisen aineiston raportoinnissa määrälliseen aineiston kautta saatuihin tuloksiin. 
Lisäksi olen suorien lainausten avulla tuonut esiin arvioijien omat äänet tulosten raportoinnissa. Käsityksiä tutkittaessa on myös hyvä muistaa niiden muuttuva ja kontekstuaalinen luonne (Barcelos \& Kalaja, 2011): arvioijien kirjoittamien huomioiden taustalta löytyi samankaltaisen käsitysten lisäksi myös ristiriitaisia ja toisistaan poikkeavia käsityksiä, mikä on hyvä huomioida tuloksia yleistettäessä.

\section{LÄHTEET}

Aho, E., Toivola, M., Karlsson, F. \& Lennes, M. (2016). Aikuisten maahanmuuttajien suomen ääntämisestä. Puhe ja kieli, 32, 77-96.

Ahola, S. 2012. Yleisten kielitutkintojen laatijoiden käsityksiä kielestä ja tehtävien laadinnasta. Lisensiaatintyö. Jyväskylän yliopisto, Soveltavan kielentutkimuksen keskus.

Ahola, S. 2016. Puhetta arvioinnista: yleisten kielitutkintojen arvioijien käsityksiä arvioinnista. Teoksessa A. Huhta, \& R. Hildén (toim.), Kielitaidon arviointitutkimus 2000-luvun Suomessa, 89-109. AFinLA-e: soveltavan kielitieteen tutkimuksia, 9. Suomen soveltavan kielitieteen yhdistys. Verkkojulkaisu: http://journal.fi/afinla/article/view/60848

Ahola, S. 2020. Sujuvaa mutta viron kielen vaikutusta. Virittäjä, 124, https://doi. org/10.23982/vir.79831

Ahola, S. \& Tossavainen, H. 2016. Helppoa vai vaikeaa arvioida?: Yleisten kielitutkintojen suomen kielen arvioijien käsityksiä vironkielisten arvioinnista. Lähivõrdlusi/ Lähivertailuja 26. Eesti Rakenduslingvistika Uhing.

Anderson-Hsieh, J., Johnson, R. \& Koehler, K. (1992). The relationship between native speaker judgments of nonnative pronunciation and deviance in segmentais, prosody, and syllable structure. Language Learning, 42, 529-555.

Ang-Aw, H. T. \& Goh, C. C. M. (2011). Understanding discrepancies in rater judgement on national-level oral examination tasks. RELC Journal, 42, 31-51.
Aragão, R. (2011). Beliefs and emotions in foreign language learning. System, 39, 302-313.

Attali, Y. (2015). A comparison of newly-trained and experienced raters on a standardized writing assessment. Language Testing, 33, 99-115.

Ballard, L. \& Winke, P. (2017). Students' attitudes towards English teachers' accents: The interplay of accent familiarity, comprehensibility, intelligibility, perceived native speaker status, and acceptability as a teacher. Teoksessa T. Isaacs \& P. Trofimovich (toim.), Second Language Pronunciation Assessment. Interdisciplinary Perspectives, (s. 121-139). Bristol: Multilingual Matters.

Barcelos, A. M. F. (2003). Researching beliefs about SLA: A critical view. Teoksessa P. Kalaja \& A. M. F. Barchelos (toim.), Beliefs about SLA: New Research Approaches, (s. 7-34). Dordrecht: Kluwer Academic Press.

Barcelos, A. M. F. \& Kalaja, P. (2011). Introduction to Beliefs about SLA revisited. System, 39, 281-289.

Bent, T. \& Holt, R.F. (2017). Representation of speech variability: Speech variability. WIREs Cognitive Science, e01434. doi: 10.1002/ wcs.1434.

Bradlow, A. R. \& Bent, T. (2008). Perceptual adaptation to non-native speech. Cognition, 106, 707-729. 
Browne, K. \& Fulcher, G. (2017). Pronunciation and Intelligibility in Assessing Spoken Fluency. Teoksessa T. Isaacs \& P. Trofimovich (toim.), Second Language Pronunciation Assessment. Interdisciplinary Perspectives (s. 37-53). Bristol: Multilingual Matters.

Carey, M. D., Mannel, R. H. \& Dunn, P. K. (2011). Does a rater's familiarity with a candidate's pronunciation affect the rating in oral proficiency interviews? Language Testing, 28, 201- 219.

Cargile, A. C. \& Giles, H. (1997). Understanding language attitudes: Exploring listener affect and identity. Language \& Communication, 17, 195-217.

Derwing, T. M. \& Munro, M. J. (1997). Accent, intelligibility, and comprehensibility; Evidence from Four L1s. Studies in Second Language Acquisition, 19, 379-398.

Eckes, T. (2005). Examining rater effects in TestDaf writing and speaking performance assessments: A many-facet Rasch analysis. Language Assessment Quarterly, 2, 197-221.

Eckes, T. (2008). Rater types in writing performance assessments: A classification approach to rater variability. Language Testing, 25, 155-185.

Fillmore, C. J. (1979). On fluency. Teoksessa C. J. Fillmore, D. Kempler \& W.S-Y. Wang (toim.) Individual differences in language ability and language behavior (s. 85-102). London: Academic Press.

Finlex (2004): Valtioneuvoston asetus yleisistä kielitutkinnoista, annettu Helsingissä 16.12.2004/1163. Finlex. Haettu 20.1.2020 osoitteesta https://www.finlex.fi/fi/laki/ ajantasa/2004/20041163.

Gass, S. \& Varonis, E. M. (1982). The Comprehensibility of non-native speech. Studies in Second Language Acquisition, 4, 114-136.

Gass, S. M. \& Varonis, E. M. (1984). The effect of familiarity on the comprehensibility of nonnative speech. Language Learning, 34, 65-87.

Giles, H \& Rakić, T. (2014). Language Attitudes: Social Determinants and Consequences of Language Variation. Teoksessa T. M. Holtgraves (toim.), The Oxford Handbook of Language abd Social Psychology (s. 11-26).
Hamps-Lyons, L. \& Davies, A. (2008). The Englishes of English tests: Bias revisited. World Englishes, 27, 26-39.

Honko, M. (2017). Kieli ja kielitaitokäsitykset tutkivan opettajan kenttäpäiväkirjamerkinnöissä. Puhe ja kieli, 37, 215-238.

Ilola, M. (2018). Oppilaiden käsityksiä englannin suullisesta kielitaidosta, sen oppimisesta ja arvioinnista. Väitöskirja. JYU dissertations 15. Haettu osoitteesta 1.2.2020 http://urn.fi/ URN:ISBN:978-951-39-7548-7.

Isaacs, T. \& Trofimovitch, P. (2012) Deconstructing comprehensibility: Identifying the linguistic influences on listeners' L2 comprehensibility ratings. Studies in Second Language Acquisition, 34, 475-505.

Johnson, J. S. \& Lim, G. (2009). The influence of rater language background on writing performance assessment. Language Testing, 26, 485-505.

Kalaja, P. \& Barcelos, A. M. F. (2003). Introduction. Teoksessa P. Kalaja, \& A. M. F. Barcelos (toim.), Beliefs about SLA: New Research Approaches, 1-4. Dordrecht: Kluwer Academic Publishers. Educational Linguistics, 2.

Kang, O. \& Rubin, D. L. (2009). Reverse Linguistic Stereotyping: Measuring the Effect of Listener Expectations on Speech Evaluation. Journal of Language and Social Psychology, 28, 441-456.

Kennedy, S. \& Trofimovich, P. (2008). Intelligibility, comprehensibility, and accentedness of L2 speech: the role of listener experience and semantic context. The Canadian Modern Language Review, 64, 459-489.

Ketolainen, I., Laakso, M. \& Simberg, S. (2017). 16-17-vuotiaiden suomalaisnuorten puheäänen korkeus. Puhe ja kieli, 37, 259-277.

Kim, Y-H. (2009). An investigation into native and non-native teachers' judgments of oral English performance: A mixed methods approach. Language Testing, 26, 187-217.

Kim, H. J. (2015). A qualitative analysis of rater behavior on an L2 speaking assessment. Language Assessment Quarterly, 12, 239-261.

Kormos, J. \& Dénes, M. (2004). Exploring measures and perceptions of fluency in the speech of second language learners. System, 32, 145-164. 
Leino, T., Laukkanen A-M., Ilomäki, I. \& Mäki, E. (2008). Assessment of vocal capacity of Finnish university students. Folia Phoniatrica et Logopaedica, 60, 199-209.

Leinonen, A. (2015). "Riittää, kun saa selvää": vieraalla aksentilla tuotettu suomi nuorten arvioimana. Väitöskirja. Jyväskylä Studies in Humanities 275. Jyväskylä: University Printing House.

Linacre, J. M. (2009). A user's guide to FACETS v3.66.0. Chigaco: Winsteps.

Lindemann, S. (2017). Variation of 'Error'? Perception of Pronunciation Variation and Implications for Assessment. Teoksessa T. Isaacs \& P. Trofimovich (toim.) Second Language Pronunciation Assessment. Interdisciplinary Perspectives (s. 193-209). Bristol: Multilingual Matters.

Lumio, M.(2014).Hymyn takana - thainmaalaiset maahanmuuttajat ja suomalais-thainmaalaiset avioliitot. Teoksessa E. Heikkilä, Oksi-Walter P. ja M. Säävälä (toim.) Monikulttuuriset avioliitot sillanrakentajina, 36-51. Siirtolaisinstituutti. Turku: Painosalama Oy. Haettu 3.7.2019 osoitteesta http://www.migrationinstitute.fi/ files/pdf/A46.pdf.

Lumley, T. \& McNamara, T. F. (1995). Rater characteristics and rater bias: Implications for training. Language Testing, 12, 54-71.

May, L. A (2006). An examination of rater orientation on a paired candidate discussion task through stimulated verbal recall. Melbourne Papers in Language Testing, 11, 29-51.

Mayring, P. (2014). Quantative Content Analysis. Theoretical foundation, basic procedures and software solutions. Austria: Klagenfurt. Haettu 21.2.2020 osoitteesta: https://www.psychopen. eu/fileadmin/user_upload/books/mayring/ ssoar-2014-mayring-Qualitative_content_ analysis_theoretical_foundation.pdf.

Major, R. C., Fitzmaurice, S. F., Bunta, F. \& Balasubramanian, C. (2002). The effects of nonnative accents on listening comprehension: Implications for ESL assessment. TESOL Quarterly, 36, 173-190.

Mercer, S. (2011). Language learner self-concept: Complexity, continuity and change. System, 39, 335-346.
Mora, J. C. \& Darcy, I. (2017). The Relationship between Cognitive Control and Pronunciation in a Second Language. Teoksessa T. Isaacs \& P. Trofimovich (toim.) Second Language Pronunciation Assessment. Interdisciplinary Perspectives (s. 5-120). Bristol: Multilingual Matters.

Munro, M. J. \& Derwing, T. (1995). Foreign accent, comprehensibility, and intelligibility in the speech of second language learners. Language Learning, 45, 73-97.

Mustonen, S. (2005). "Hei sta Thainmaassa": thainkielisen suomenoppijan paikallissijailmaukset konseptuaalisen semantiikan näkökulmasta. Pro gradututkielma. Jyväskylän yliopisto, kielten laitos.

Nikonen, M. (2012). Kysymysten prosodiaa ja syntaksia. Thainkielisten suomenoppijoiden kysyvät konstruktiot keskustelussa. Pro gradututkielma. Helsingin yliopisto.

Negueruela-Azarola, E. (2011). Beliefs as conceptualizing activity: A dialectical approach for the second language classroom. System, 39, 359-369.

Olkkonen, S. \& Peltonen, P. (2017). Mitä on toisen kielen sujuvuus? Näkökulmia kognitiivisen ja puhetuotoksen sujuvuuden tutkimuksesta. Näkökulmia toisen kielen pubeeseen - Insights into second language speech, A-FinLa-E, 234257.

Orr, M. (2002). The FCE Speaking test: Using rater reports to help interpret test scores. System, 30, 143-154.

Peng, J-E. (2011). Changes in language learning beliefs during a transition to tertiary study: The mediation of classroom affordances. System, 39, 314-324.

Riney T. J, Tagaki, N. \& Inutsuka, K. (2005). Phonetic parameters and perceptual judgements of accent in English by American and Japanese listeners. TESOL Quarterly, 39, 441-466.

Saarinen, T., Kauppinen, M. \& Kangasvieri, T. 2019. Kielikäsitykset ja oppimiskäsitykset koulutuspolitiikkaa linjaamassa. Teoksessa T. Saarinen, P. Nuolijärvi, S. Pöyhönen, \& T. Kangasvieri (toim.), Kieli, koulutus, politiikka: monipaikkaisia käytänteitä ja tulkintoja (s. 121-148). Vastapaino. 
Saito, K., Trofimovich, P., Isaacs, T. \& Webb, S. (2017). Re-examining phonological and lexical correlates of second language comprehensibility: The role of rater experience. Teoksessa T. Isaacs \& P. Trofimovich (toim.), Second language pronunciation assessment. Interdisciplinary perspectives (s. 141-156). Bristol: Multilingual Matters.

Salo, O-P. (2009). Dialogisuus kielikasvatuksen kehyksenä. Pube ja kieli, 29, 89-102.

Sato, T. (2011). The contribution of test takers' speech content to scores on an English oral proficiency test.Language Testing, 29, 223-241.

Schreier, M. (2014). Quantative Content Analysis. Teoksessa U. Flick (toim.), The SAGE Handbook of Qualitative Data Analysis (s. 170-183). doi: https://dx.doi. org/10.4135/9781446282243.

Shi, L. (2001). Native- and nonnative-speaking EFL teachers' evaluation of Chinese students' English writing. Language Testing, 18, 303-325.

Shinyella, T. (2012). Kaksikulttuurista arkea suomalais-thainmaalaisissa lapsiperheissä. Selvitys suomalaisthainmaalaisten lapsiperheiden tilanteesta sekä erityispiirteistä, -tarpeista ja -haasteista. Monikulttuuriyhdistys Familia Club ry. Haettu 3.7.2019 osoitteesta http://www. duoduo.fi/uploads/1/6/8/8/16885322/kirkaksikulttuurista-arkea.pdf .

Sirkkilä, H. (2005). Elättäjyyttä vai erotiikkaa. Miten suomalaiset miehet legitimoivat parisubteensa thainmaalaisen naisen kanssa? Väitöskirja. Jyväskylä Studies in Education. Psychology and Social Research 268. Jyväskylä University Printing House.
SVT (2018). Suomen virallinen tilasto: Väestörakenne Väestö kielen, iän ja sukupuolen mukaan 1990-2018, Helsinki: Tilastokeskus. Haettu 10.1.2020 osoitteesta: https://www. stat.fi/tup/maahanmuutto/maahanmuuttajatvaestossa.html.

Tarnanen, M. (2002). Arvioija valokeilassa: suomi toisena kielenä kirjoittamisen arviointia. Soveltavan kielentutkimuksen keskus, Jyväskylän yliopistopaino.

Tuomi, J. \& Sarajärvi, A. (2009). Laadullinen tutkimus ja sisällönanalyysi. Helsinki: Tammi.

Yleiset kielitutkinnot (2003). Pubumisen arviointikriteerit. Haettu 21.02.2020 osoitteesta: https://www.jyu.fi/hytk/fi/laitokset/ solki/yki/yleista/tietoakielitutkinnoista/ puhumisen_arviointikriteerit.pdf.

Winke, P., Gass, S. \& Myford, C. (2013). Raters' L2 background as a potential source of bias in rating oral performance. Language Testing, 30, 231-252.

Woods, D. (2003). The social construction of beliefs in the language classroom. Teoksessa P. Kalaja \& A. M. F. Barchelos (toim.), Beliefs about SLA: New Research Approaches, (s. 201-229). Dordrecht: Kluwer Academic Press.

Woods, D. \& Çakir, H. (2011). Two dimensions of teacher knowledge: The case of communicative language teaching. System, 39, 381-390. 


\section{THE NATIONAL CERTIFICATES FINNISH RATERS' PERCEPTIONS OF L1 THAI SPEAKERS' SPOKEN FINNISH SKILLS}

Sari Ahola, University of Jyväskylä, Centre for Applied Language Studies

This article examines how the recognition of the $\mathrm{L} 1$ of Finnish learners of Thai origin $(\mathrm{N}=10)$ affects the National Certificates Finnish raters' $(\mathrm{N}=44)$ perceptions of language skills and what perceptions the raters have on Thai speakers' oral proficiency. The data comes from the project 'Broken Finnish' in which Thai speakers form one of the researched migrant groups. By means of quantitative data, the article examines L1 recognition and the use of the six analytic criteria for assessment. The qualitative data consist of observations of recognising L1 and the learners' language skills, which the raters wrote down during assessment. These were analysed using theory driven content analysis.

The raters could easily recognise the women $(\mathrm{N}=8)$ as $\mathrm{L} 1$ Thai speakers, but not the men $(\mathrm{N}=2)$. The recognition clearly had an effect on rating the proficiency levels: the recognised speakers got lower marks on pronunciation and grammatical accuracy but were rewarded for fluency and the control of the general criterion. The raters considered it difficult for the Thai speakers to learn the pronunciation of the target language because of L1. Grammatical problems were regarded as a consequence of shortcomings in formal education. Fluency, connected with active speech production, was considered the strength of L1 Thai speakers' language proficiency. The ratings of the general criterion (covers all criteria) were linked with understanding the learner product. The perceptions of the learners' skills were further affected by the raters' knowledge of Thai speakers' life in Finland and, in particular, by stereotypical thinking patterns connected to women.

Keywords: Finnish L2 learners, language assessment, language beliefs, raters, speaking skills, Thai speakers 
224 